\title{
WAJAH BARU PENDIDIKAN ISLAM INDONESIA: JILBAB, TOLERANSI, DAN SKB 3 MENTERI
}

\author{
Muh. Iqbal ${ }^{1}$ \\ ${ }^{1}$ Universitas Ahmad Dahlan, Yogyakarta \\ *Corresponding email: iqbal2007052019@webmail.uad.ac.id
}

Naskah diterima: 18 Juli 2021| Disetujui: 16 Agustus2021 | Diterbitkan: 18 Agustus 2021

\begin{abstract}
The problem of schools applying the rules to use school uniforms (hijab) is considered as coercion to use certain religious attributes and is considered as intolerant and violates human rights. This is also what underlies the three ministerial decrees on school uniforms that were issued as a form of government effort to strengthen religious tolerance in educational institutions. The research approach is descriptive qualitative with literature study research methods, data collection techniques are carried out by tracing library sources (e-journals, books, laws and regulations, and online news). The data analysis technique uses content analysis techniques (content analysis)..The results of the study in the form of forcing hijab at school is an act of intolerance and is against religion. The Decree of 3 Ministers is an effort to increase tolerance in educational institutions. The solution so that the rules for using the hijab in schools are not intolerant, then the hijab worn by school residents is in accordance with the teachings of their respective religions. SKB as a policy to strengthen interreligious tolerance starting from educational institutions by not forcing students to use uniforms or attributes with specific religious characteristics.
\end{abstract}

Keywords: Religion.,Hijab, SKB.,Tolerance

Abstrak: Persoalan sekolah yang menerapkan aturan untuk menggunakan seragam sekolah (jilbab) dianggap sebagai pemaksaan terhadap atribut keagamaan tertentu. Hal ini juga yang mendasari SKB Tiga Menteri tentang seragam sekolah dikeluarkan sebagai bentuk upaya pemerintah dalam menguatkan toleransi beragama di lembaga pendidikan. Pendekatan dalam penelitian ini berupa kualitatif deskriptif dengan metode penelitian studi pustaka, sedangkan teknik pengumpulan data dilakukan dengan menelusuri sumber yang bersifat kepustakaan (e-jurnal, buku, peraturan perundang-undangan, serta berita online). Adapun teknik analisis data menggunakan analisis isi (content analysis). Penelitian ini bertujuan untuk menganalisis kasus latar belakang dikeluarkannya SKB Tiga Menteri dari sudut agama yang diakui di Indonesia dan bagaimana SKB menguatkan toleransi beragama di lembaga pendidikan. Hasil penelitian berupa pemaksaan jilbab di sekolah merupakan tindakan intoleran dan bertentangan dengan agama. Adapun SKB Tiga Menteri sebagai upaya untuk meningkatkan toleransi di lembaga pendidikan. Solusi agar aturan menggunakan jilbab di sekolah tidak intoleran, maka jilbab yang dikenakan warga sekolah sesuai dengan ajaran agama masing-masing. SKB sebagai kebijakan untuk menguatkan toleransi antar agama yang di mulai dari lembaga pendidikan dengan tidak memaksa peserta didik menggunakan seragam atau atribut dengan kekhasan agama tertentu.

Kata kunci: Agama, Jilbab, SKB, Toleransi 


\section{PENDAHULUAN}

Awal tahun 2021 dunia pendidikan kembali dihebohkan dengan munculnya polemik yaitu salah satu lembaga pendidikan di kota Padang, Sumatera Barat mewajibkan siswanya yang non-muslim untuk mengenakan jilbab. Hal tersebut dilakukan oleh kepala sekolah sebagai bentuk menjalankan aturan penggunaan wajib jilbab untuk siswi merujuk pada instruksi wali kota Padang Nomor 451.442/BINSOS-iii/2005 tentang aturan penggunaan jilbab (Nurita, 2021). Ujung dari viralnya kasus ini bahwa pemaksaan jilbab dianggap sebagai tindakan intoleran dan pelanggaran HAM (CNN Indonesia, 2021).

Di saat kasus tersebut mencuat dan ramai diperbincangkan oleh media, pemerintah merespon kasus tersebut dengan Surat Keputusan Bersama Tiga Menteri (Mendikbud, Mendagri, dan Menteri Agama) tentang penggunaan seragam dan atribut bagi peserta didik, pendidik, dan tenaga kependidikan di lingkungan sekolah yang diselenggarakan oleh pemerintah daerah pada jenjang pendidikan dasar dan menengah. Dikutip dari laman berita resmi kementerian Agama RI, Menteri Agama menyampaikan latar belakang SKB karena pada dasarnya nilai-nilai agama mengajarkan perdamaian, menyelesaikan perbedaan, serta saling menghormati (Kontri, 2021). Oleh karena itu diharapkan dapat memperkuat toleransi antar umat beragama di Indonesia.

Keluarnya SKB tersebut menuai banyak pro dan kontra. Ketua MUI Sumatera Barat secara personal menyampaikan bahwa tidak mengizinkan pihak mana pun yang membuat kebijakan dan berdampak melepaskan jilbab/penutup aurat bagi putra/putri Minangkabau. Terlebih orang tua peserta didik sudah bertanda tangan di dalam tata tertib yang ada di sekolah. Di samping itu beliau juga menyampikan persoalannya dapat diselesaikan secara internal sekolah, tidak harus sampai dibawa keluar sampai harus menggunakan power kekuasaan (TV Padang, 2021). Di sisi lain sekjen FSGI mengatakan pihaknya mendukung sepenuhnya SKB Tiga Menteri tersebut (Bahtiar, 2021a). Wasekjen FGSI juga menyampaikan terkait SKB Tiga Menteri harus direvisi karena di dalamnya tidak memuat sanksi yang jelas bagi pelanggar dan perlu disosialisasikan secara masif minimal satu tahun. (Bahtiar, 2021b) Sejatinya SKB 3 Menteri di keluarkan guna menjaga kerukunan antar umat agama dan bangsa dengan penanaman toleransi dan menegaskan bahwa atribut dan seragam sekolah merupakan bagian dari moderasi beragama (Kementerian Pendidikan dan kebuyaan, 2021: 2).

Persoalan tersebut pula yang menjadi kegelisahan peneliti, di mana pendidikan pendidikan Islam seharusnya menjadi terdepan dalam penanaman sikap toleransi. Persoalan tersebut tidak dapat dianggap remeh terlebih menyangkut persoalan agama dan atributnya (jilbab). Terlebih upaya penerapan jilbab di sekolah sebagai bagian untuk menanamkan karakter religius pada peserta didik. Akan tetapi peraturan sekolah yang menerapkan aturan mengenakan jilbab atau kerudung 
khususnya di sekolah negeri dianggap sebagai upaya Islamisasi (Wahyuni, 2019: 89). Bersamaan dengan itu peneliti mencoba menguraikan persoalan tersebut dengan tema jilbab dan toleransi.

Dengan menggunakan penelitian literatur review, dan pendekatan kualitatif deskriptif serta analisis mendalam terhadap sumber data, maka tujuan penelitian ini untuk menganalisis SKB Tiga Menteri sebagai upaya menguatkan toleransi beragama dalam pendidikan khususnya pendidikan Islam. Dalam tulisan ini akan dijabarkan bagaimana pemaksaan jilbab sebagai pelanggaran toleransi, toleransi beragama dalam pendidikan Islam, serta bagaimana SKB Tiga Menteri ini menguatkan toleransi antar agama dalam pendidikan tanpa menimbulkan konflik. Terlebih dalam problem penyebab keluarnya SKB Tiga Menteri diakibatkan oleh penggunaan atribut keagamaan di suatu lembaga pendidikan.

Telah banyak kajian tentang toleransi beragama di dalam pendidikan Islam, salah satunya Akhmad (2020) yang menyampaikan untuk mencapai tujuan dan kompetensi yang diharapkan dari pendidikan Islam khususnya toleransi agama, maka materi-materi yang diajarkan disusun untuk dapat meningkatkan toleransi bagi sesama umat manusia (Akhmad, 2020: 67). Akan tetapi masih jarang di temukan bahasan yang membahas SKB Tiga Menteri tentang penggunaan seragam di sekolah yang dikelola oleh pemerintah daerah. Oleh karena itu, penulis beranggapan bahwa isu toleransi terkait SKB ini perlu dianalisis dan dikaitkan dengan kajian lain guna memperluas kajian ilmu pengetahuan, serta dapat dijadikan sebagai kajian dalam merumuskan kebijakan pendidikan khususnya dalam persoalan agama dan toleransi. Perbedaan lain dari penelitian ini dengan penelitian sebelumnya yakni penelitian ini menguraikan bagaimana solusi agar penggunaan jilbab di sekolah tetap dapat diterapkan di bawah naungan pemerintah tanpa perlu dianggap intoleran.

Penelitian ini didasarkan pada argumen bahwa keputusan sekolah untuk mewajibkan murid, pendidik, dan tenaga kependidikan mengenakan pakaian dan atribut untuk menutup aurat adalah bagian dari proses pendidikan (Majelis Ulama Indonesia, 2021). Membahas terkait atribut keagamaan khususnya hijab, dalam agama lain selain Islam juga mengajarkan menggunakan penutup kepala untuk menutup aurat. Pendidikan sebagai upaya untuk mengembangkan kepribadian individu dalam beragama atau pun berbangsa dan bernegara (Fattah, 2014: 44). Oleh karena itu, di dalam pendidikan sangat penting di ajarkan toleransi. Toleransi dalam pendidikan merupakan suatu poin penting sebagaimana kita ketahui Indonesia merupakan bangsa yang heterogen, terdiri dari berbagai suku, ras, dan agama yang beragam (Mokodenseho and Wekke, 2017: 72).

Sebelum membahas lebih jauh, penulis perlu menyamakan persepsi tentang jilbab, guna mencegah miskonsepsi. Secara sederhana jilbab yaitu pakaian atau kain yang menutup seluruh tubuh mulai dari ujung kepala sampai kaki (Al-Barik, 2017: 149). Terkadang jilbab ini di sama dengan 
kerudung yang memiliki arti kain untuk menutup kepala (KBBI, n.d.). Sebagai muslimah semua tahu bahwa umat Islam mewajibkan umatnya untuk menutup aurat, lantas bagaimana dengan agama lain apakah sama. Ajaran agama Kristen dalam Kitab Perjanjian Baru di jelaskan

Dan kalau seorang wanita pada waktu berdoa atau pada waktu menyampaikan berita dari Allah di hadapan banyak orang, tidak memakai tutup kepala, maka wanita itu menghina suaminya yang menjadi kepala atas dirinya. Itu sama saja seolah-olah kepala wanita itu sudah di cukur. Sebab kalau seorang wanita tidak mau memakai tutup kepala lebih baik rambutnya digunting. Tetapi kalau seorang wanita dicukur kepalanya atau digunting rambutnya, maka itu suatu penghinaan bagi dia. Oleh sebab itu lebih baik ia memakai tutup kepala (Kitab I Korintus, 11: 5-6)

Sebab itu, untuk menyenangkan para malaikat, seorang wanita harus memakai tutup kepala sebagai tanda bahwa ia di bawah kekuasaan suaminya. Meskipun begitu dalam kehidupan kita sebagai orang Kristen, wanita tidak berdiri sendiri, lepas dari laki-laki, dan laki-laki pun tidak berdiri sendiri, lepas dari wanita (Kitab I Korintus, 11: 10-11) (Alkitab Perjanjian Baru Dalam Terjemahan Sederhana Indonesia, 2014: 461-62).

Dari kitab tersebut dapat di pahami bahwa baik perempuan Islam dan Kristen juga diwajibkan untuk berjilbab. Memang kitab tersebut tidak secara eksplisit menyebutkan bahwa yang belum menikah pun harus menutup kepala akan tetapi dapat di pahami bahwa pendidikan itu semestinya di mulai sejak dini. Oleh karena itu, penggunaan jilbab juga harus di tanamkan sejak dini. Terkait penggunaan jilbab sudah dicontohkan oleh Bunda Mariah ibunda Yesus Kristus (Syafi'in, 2007: 113).

Dalam agama Hindu juga dijumpai ajaran tentang jilbab "Rama berkata kepada Shinta, dia memerintahkan agar menundukkan pandangan dan mengenakan kerudung." [Mahavir Charitra Act 2 Page 71] (Tauhid, 2011; Syarah, 2020: 70). Walaupun demikian persoalan adanya anjuran pemakaian tudung kepala wanita dalam agama Hindu lebih dominan karena pengaruh budaya India (Syarah, 2020: 72). Di dalam agama Buddha juga diperhatikan salah satu dewinya yaitu Dewi Kwan Im juga mengenakan kain di kepalanya. Pada dasarnya ajaran jilbab/hijab tidak dimonopoli oleh agama Islam semata, melainkan juga menjadi syariat dari agama-agama yang diakui di Indonesia (Rahmi, 2016).

Dengan banyaknya keyakinan yang ada di Indonesia, maka setiap manusia dituntut untuk saling menghormati dan toleransi. Toleransi berasal dari kata tolerare berarti "sabar terhadap sesuatu, menghargai orang lain" (Bakar, 2015: 123). Dalam bahasa Arab disebut al-tasamuh yang bermakna tenggang rasa atau membiarkan (Suryan, 2017: 186). Dengan demikian dapat dipahami bahwa toleransi adalah sikap sabar, tenggang rasa, dan saling menghargai dalam setiap aspek kehidupan. 
Jika ditarik dalam konteks beragama adalah sikap saling menghargai dan tidak mengganggu atau melecehkan penganut agama lain dalam menjalankan ajaran agamanya.

Pendidikan Islam dan toleransi adalah sesuatu yang tidak dapat dipisahkan. Terlebih dalam sumber ajaran Islam (Al-Qur'an dan hadis) terdapat banyak ayat yang menunjukan sikap toleransi. Seperti QS. Al-Hujurat [49]: 13 yang artinya:

Wahai manusia, sesungguhnya kami telah menciptakan kamu dari seorang laki-laki dan seorang perempuan, kemudian kami jadikan kamu berbangsa-bangsa dan bersuku- suku supaya kamu saling kenal- mengenal. Sesungguhnya orang yang paling mulia diantara kamu disisi Allah ialah orang yang paling taqwa diantara kamu. Sesungguhnya Allah Maha mengetahui lagi Maha Mengenal. "(Departemen Agama RI, Cordova Al-Qur'an \& Terjemah, 2009)

Ayat lain seperti QS. Al-Kafirun [109]: 6 yang artinya "untukmu agamamu dan untukku agamaku”.

Dari beberapa ayat di atas dapat dipahami bahwa agama Islam menghargai adanya pluralitas, tidak menepikan bahwa adanya agama lain selain Islam serta tidak boleh ada unsur pemaksaan dalam menganut ajaran Islam, maka pada dasarnya nilai-nilai tersebut mencerminkan sikap toleransi sebagai bagian dari karakter umat Islam.

SKB Tiga Menteri adalah aturan yang di keluarkan atas kesepakatan bersama tiga menteri yaitu Menteri dalam Negeri, Menteri Agama, dan Menteri Pendidikan dan kebudayaan yang berisi tentang penggunaan seragam dan atribut bagi peserta didik, pendidik, dan tenaga kependidikan di lingkungan sekolah yang diselenggarakan oleh pemerintah daerah pada jenjang pendidikan dasar dan menengah. Aturan tersebut keluar guna meningkatkan sikap toleransi di dalam dunia pendidikan dan disahkan pada tanggal 03 Februari tahun 2021. Adapun poin-poin penting yang ada di dalam SKB 3 Menteri adalah sebagai berikut:

1. Warga sekolah yang diselenggarakan oleh pemerintah berhak memilih dan menggunakan seragam dengan memperlihatkan unsur kekhasan agama tertentu atau tidak selama sesuai dengan peraturan perundang-undangan.

2. Pemerintah daerah dan pihak sekolah dilarang untuk mensyaratkan, mewajibkan dan memerintahkan warga sekolahnya menggunakan seragam dengan kekhasan agama tertentu. Hal ini sebagai upaya untuk perlindungan hak peserta didik, pendidik, dan tenaga kependidikan

3. Perintah daerah dan pihak sekolah wajib mencabut aturan, kebijakan, instruksi dan lain-lain yang bertentangan dengan SKB 3 Menteri 
4. Sanksi bagi sekolah yang melanggar berupa sanksi tertulis dan sanksi lain sesuai aturan perundang-undangan yang ada, serta dilakukan pembinaan oleh kementerian agama.

5. Aturan ini tidak berlaku bagi provinsi Aceh dengan pertimbangan peraturan perundangundangan mengenai pemerintahan Aceh sebagai daerah Istimewa.

\section{METODE}

Penulisan artikel mengenai wajah baru pendidikan Islam Indonesia: jilbab, toleransi dan SKB 3 menteri bersifat kualitatif deskriptif dalam bentuk eksplorasi kepustakaan, yang didasarkan pada berita online dan literatur di bidang pendidikan Islam, serta literatur terkait lainnya yang menyangkut toleransi di lembaga pendidikan dan SKB 3 Menteri. Masalah yang dialami berupa aturan penggunaan jilbab bagi siswa non-muslim di sekolah di bawah naungan pemerintah adalah suatu tindakan intoleran dan melanggar aturan perundang-undangan. Teknik pengumpulan data dilakukan dengan menelusuri referensi terkait, berupa referensi digital seperti berita online, e-journal, $e$ document, buku, dokumen, Undang-Undang, karya ilmiah dan sumber kepustakaan lainnya (Zed, 2008: 3) yang berhubungan dengan dampak pemaksaan pembelajaran daring selama masa pandemi. Penelusuran referensi dilakukan dengan menelusuri hal-hal yang terkait dengan dampak pembelajaran daring selama masa pandemi. Data-data yang terkumpul kemudian direduksi dan direkonstruksi menjadi konsep baru yang utuh dan fresh. Analisis data dilakukan dengan menggunakan analisis isi yang mengedepankan intertekstualitas dan meaning creativity.

Analisis isi (Content Analysis) di mana memaparkan secara mendalam terhadap permasalahan atau informasi yang dimuat dalam sumber data (Emzir, 2014: 283). Adapun teknik pengumpulan data terdiri dari beberapa langkah, yaitu: 1) mengumpulkan literatur/data kepustakaan yang berkaitan dengan tema dan tujuan penelitian, 2) mengelompokkan sumber data, 3) mengutip data yang di perlukan.

\section{HASIL DAN PEMBAHASAN}

\section{Pemaksaan Jilbab adalah Intoleran}

Mencermati kasus yang menjadi latar belakang munculnya SKB Tiga Menteri jika dilihat dalam konteks dakwah, maka tidak ada salahnya suatu lembaga pendidikan mewajibkan muridnya untuk menutup aurat (memakai hijab). Seperti yang disampaikan oleh MUI bahwa pendidikan itu bukan sekadar transfer ilmu pengetahuan akan tetapi juga transfer nilai-nilai dan keteladanan (Majelis Ulama Indonesia, 2021). 
Aturan penggunaan jilbab bagi siswa non-muslim terlebih yang sangat menonjolkan ciri agama tertentu merupakan bagian dari pelanggaran Hak Asasi Manusia. Hal ini dapat tercermin dalam QS. Al-Baqarah ayat 256 yang intinya tidak ada paksaan dalam memeluk agama Islam. Di sisi lain kehidupan masyarakat Indonesia yang heterogen tentu menuntut lembaga pendidikan yang menerapkan moderasi beragama. Dari landasan yuridis, tidak ditemukan regulasi peraturan yang mensyaratkan penggunaan atribut atau seragam kekhasan agama tertentu.

Memang tidak salah sebuah lembaga pendidikan menerapkan aturan yang meningkatkan religiusitas peserta didikannya, namun perlu mempertimbangkan masyarakat yang heterogen, jangan sampai menimbulkan kesan bahwa lembaga sekolah tidak mengajarkan toleransi antar umat beragama (moderasi beragama). Hal ini juga termasuk bagi lembaga pendidikan yang berada di lingkungan masyarakat Islam, sebelum membuat kebijakan sangat penting untuk memperhatikan kaidah-kaidah di dalam ajaran Islam terlebih Islam disebut sebagai agama dakwah (Hendra, 2017: 165). Walaupun tujuannya untuk berdakwah tapi perlu memperhatikan kaidah-kaidah dakwah yang ada. Sebagaimana yang terdapat di dalam QS. Al-Imran: 40 yang artinya:

surat Al-Imran: 104 yang artinya “dan hendaklah di antara kamu ada segolongan orang yang menyeru kepada kebajikan, menyuruh (berbuat) yang makruf dan mencegah dari yang mungkar. Dan mereka itu adalah orang-orang yang beruntung”.'(Departemen Agama RI, Cordova Al-Qur'an \& Terjemah, 2009)

Dari ayat di atas terdapat kata "menyeru dan menyuruh", bagi peneliti hal tersebut diartikan sebagai ungkapan untuk mendidik manusia menjadi lebih baik. Salah satu caranya melalui lembaga pendidikan/dakwah. Perlu digaris bawahi bahwa dalam tulisan ini peneliti mengartikan dakwah sebagai pendidikan, dengan berdasar pada esensi baik pendidikan atau dakwah untuk menyampaikan sesuatu yang baik sehingga mengubah keadaan suatu masyarakat menjadi lebih baik (Muhaemin, 2017: 341). Hal ini diterapkan Muhammadiyah, yaitu bagian dari dakwah adalah pendidikan di sekolah. Esensi dakwah di lembaga pendidikan apabila guru berperan dalam mengubah pribadi dan karakter manusia (peserta didik) menjadi lebih baik (Fajrul, 2020: 31). Dengan demikian, pendidikan tidak sekadar lisan akan tetapi juga harus diwujudkan dalam bentuk perbuatan. Adapun prinsip dakwah/pendidikan di dalam Islam adalah dilakukan dengan bijaksana, dilakukan dengan baik serta lemah lembut yang berujung pada mengubah karakteristik atau kepribadian manusia menjadi lebih baik, hal ini sejalan dengan tujuan pendidikan nasional Indonesia dalam Undang-Undang nomor. 20 tahun 2003 pasal 3, yaitu untuk mengembangkan potensi peserta didik agar menjadi manusia yang beriman dan bertakwa kepada Tuhan Yang Maha Esa, berakhlak mulia, sehat, berilmu, cakap, kreatif, mandiri, dan menjadi warga negara yang demokratis serta bertanggung jawab (Indonesia, 2003: 2). 
Apabila dilihat dari kacamata moderasi beragama, maka pemaksaan penggunaan jilbab atau atribut khas agama tertentu, berpotensi menghilangkan nilai-nilai paham moderat di dalam diri peserta didik. Moderat dalam beragama berarti sebagai ungkapan bangga akan esensi dari agama atau kepercayaan yang dianutnya (RI, 2019: 14). Jika hal tersebut terjadi maka seakan-akan peserta didik dihalangi cara padang dirinya dalam menentukan sikap berdasarkan ajaran agamanya karena terbelenggu oleh aturan yang mengharuskan mengenakan jilbab dengan kekhasan agama tertentu, sehingga kehilangan jati diri. Padahal moderasi beragama adalah cara pandang yang berada di tengah atau adil dan tidak ekstrim ke kiri atau ke kanan.

Kehilangan cara pandang tersebut sangatlah berbahaya. Dalam kajian psikologis, anak usia sekolah adalah masa di mana mereka berupaya untuk mencari jati diri, maka tugas mereka adalah mengembangkan diri, sehingga peran lembaga pendidikan harus mendorong mereka ke arah yang lebih baik tanpa ada belenggu aturan yang mengharuskan untuk mengikuti kebiasaan yang bukan bagian dari kepercayaan atau jati diri mereka. Walaupun dalam ajaran agama Islam Tuhan kita hanya satu sehingga kita harus berdakwah atau memberikan pendidikan kepada non-muslim agar kembali ke jalan yang lurus yaitu agama Islam, akan tetapi perlu juga diingat bahwa Al-Qur'an sendiri di dalam QS. Al-Baqarah ayat 256 mengatakan bahwa tidak ada paksaan dalam memeluk agama Islam. Hal ini juga berlaku bagi aturan yang mewajibkan penggunaan jilbab bercirikan Islam kepada nonmuslim.

Apabila lembaga pendidikan berupaya untuk meningkatkan pemahaman religiositas peserta didiknya ataupun untuk menciptakan ciri khas sekolah tersebut melalui penggunaan jilbab, dengan demikian bentuk solusi strategis untuk mencapai tujuan tersebut yaitu atribut yang digunakan harus berdasarkan agamanya sebagai cerminan diri peserta didik dan memunculkan kebanggaan di dalam dirinya sebagai umat beragama dengan kata lain tidak memaksakan seragam sekolah dengan kekhasan agama tertentu (Kementerian Pendidikan dan kebuyaan, 2021).

Melihat dari uraian sebelumnya bahwa memang persoalan jilbab tidak dimonopoli oleh umat Islam dalam hal ini sekolah yang menerapkan kebijakan penggunaan jilbab bagi muridnya dapat dianggap berusaha untuk menekankan dan mengamalkan apa yang ada di dalam ajaran agama. Bahkan jilbab dianggap sebagai simbol kemuliaan seorang perempuan. Namun perlu diperhatikan bahwa jilbab atau atribut tersebut sesuai dengan bentuk yang diajarkan agama dan kepercayaan peserta didik. Sehingga solusi yang tepat adalah membebaskan peserta didik menggunakan atribut penutup kepala/jilbab sesuai dengan tuntunan agamanya. Dengan demikian akan terwujud peserta didik yang bersungguh-sungguh menjalankan perintah agamanya dengan penuh rasa syukur atau memiliki kecerdasan spiritual. Dengan mengedepankan agama dalam membuat aturan akan 
melahirkan wajah baru dunia pendidikan yang tidak hanya mengedepankan ilmu pengetahuan semata akan tetapi juga akhlak dan budi pekerti yang baik.

\section{Toleransi Beragama dalam Pendidikan Islam}

Tidak dapat dipungkiri bahwa lembaga pendidikan sebagai instrumen untuk mendidik, mengarahkan dan menanamkan nilai-nilai moral dan agama dijadikan sebagai titik tolak dalam penanaman sikap toleransi di dalam diri individu, baik toleransi antar sesama agama atau pun dengan agama lain. Oleh karena itu, lembaga pendidikan harus menyusun kurikulum sekolah yang memuat basic ideas dengan ruang lingkup berupa ranah filosofis, ketentuan agama, psikologis manusia yang terlibat dalam proses pendidikan, dan sosial dengan menitiberatkan pada kondisi kemasyarakatan terkini (Mumin, 2018: 20). Iklim lingkungan sekolah harus mendukung pembentukan sikap toleransi yang diwujudkan dari kebijakan-kebijakan internal sekolah, mencontohkan hubungan sosial dan agama yang baik (Mumin, 2018, 21). Oleh karena itu. pembentukan iklim lingkungan sekolah baik sangat berpengaruh terhadap nilai-nilai norma, agama, serta hubungan sosial peserta didik (Saihu and Aziz, 2020: 220). Di samping kurikulum dan iklim, aspek lain yang perlu diperhatikan adalah kompetensi guru. Tidak dapat dipungkiri guru/pendidik merupakan figur sentral dalam proses pendidikan untuk menumbuhkembangkan potensi peserta didik, baik dari intelektual maupun moralitas (Mucharomah, 2017: 173). Kompetensi guru yang profesional dan pemahaman keilmuan yang luas sangat penting untuk mencegah peserta didik dari pemahaman yang keliru dan menyesatkan dirinya sendiri dan masyarakat.

Hal tersebut juga berlaku bagi dunia pendidikan Islam di mana sumbernya adalah kaidah dan landasan utamanya adalah Al-Qur'an dan Hadis. Maka pendidikan Islam juga harus mengajarkan nilai-nilai moderasi beragama atau toleransi. Hal ini dapat diberikan melalui pendidikan kepribadian dan akhlak. Akan tetapi tidak dapat dilakukan sekadar dalam bentuk teori, akan tetapi juga harus diajarkan dalam bentuk praktek atau pembiasan dalam kehidupan sehari-hari (Kisman, 2021: 38). Berbagai nilai toleransi yang dapat diajarkan di lembaga pendidikan Islam seperti:

\section{Menghargai}

Sekolah sebagai tempat interaksi sosial peserta didik, pendidik, dan masyarakat sekolah yang terdiri dari berbagai kepribadian, karakter, budaya, dan lain sebagainya. Perbedaan tersebut harus diakomodir sehingga menimbulkan perasaan saling menghargai sebagai awal. bagi peserta didik dalam menumbuhkan dan memperkuat nilai toleransi di masa depan (Usman and Widyanto, 2019: 44). Sikap menghargai juga dapat dituangkan dalam memberikan keleluasaan kepada pemeluk agama lain untuk mengenakan pakaian sesuai dengan agamanya selama tidak melanggar aturan 
sekolah. Contoh lain seperti memberikan kebebasan kepada peserta didik untuk tidak ikut pada mata pelajaran agama tertentu.

\section{Bersaudara}

Dengan semboyan Bhinneka Tunggal Ika yang artinya walaupun berbeda-beda tetapi tetap satu. Nilai bersaudara akan menjadi landasan yang baik dalam membangun kebersamaan di sekolah serta berguna bagi bangsa Indonesia yang heterogen, sebab perbedaan pada hakikatnya tidak dapat di hindari. Oleh karena itu, sekolah sebagai tempat interaksi sosial dituntut untuk menanamkan nilai-nilai persaudaraan dan persatuan tanpa memandang perbedaan agama. Sebagai contoh tidak boleh berkelahi, tawuran, dan hal-hal sebagainya yang dapat memecah belah.

\section{Bekerja sama}

Pendidikan sebagai proses yang humanis, menekankan manusia sebagai mahluk sosial tidak dapat menghindari adanya tolong menolong atau kerja sama. Hal ini pun berlaku kepada peserta didik, di mana mereka harus mampu bekerja sama dengan kawan-kawannya di sekolah tanpa membedakan agama serta mampu mengelola konflik. Disamping bekerja sama juga ada nilai berbagi, misalnya ketika ada kawannya yang sakit mereka bahu membahu untuk mengumpulkan sumbangan. Kemampuan mengelola konflik akan menumbuhkan peserta didik yang sadar akan keberagaman budaya, agama, menghargai kemajemukan, dan mampu menumbuhkan sikap toleransi.

\section{Tidak diskriminatif}

Tindakan diskriminatif adalah salah satu tindakan tercela yang membuat korbannya sakit hati. Oleh karena itu di dalam benak peserta didik harus ditanamkan agar menghindari perilaku diskriminatif baik kepada sesama teman atau pun kepada pemeluk agama lain. Sebagai contoh mengejek sembahan orang lain, hal semacam ini dapat dicegah dengan mengajarkan kepada peserta didik bagaimana saling menghargai dan memahami perbedaan yang ada.

Terkait persoalan jilbab di sekolah, walaupun dibenarkan di dalam kitab suci agama lain, akan tetapi sebagai pendidikan Islam harus menerapkan QS. Al-Baqarah [2]: 256, yakni ketika menyampaikan dan menerapkan aturan khususnya yang menyangkut agama hendaknya tidak mengedepankan unsur paksaan terlebih kepada agama lain.

“tidak ada paksaan dalam (menganut) agama (Islam), sungguh telah jelas (perbedaan) antara jalan yang benar dengan jalan yang sesat. Barang siapa yang ingkar kepada Thaghut dan beriman kepada Allah, maka sungguh, dia telah berpegang (teguh) pada tali yang sangat kuat yang tidak akan putus. Allah maha mendengar Maha mengetahui”. 
Islam sebagai agama yang toleran, maka lembaga pendidikan Islam juga harus mampu menerapkan prinsip toleransi atau moderasi beragama dalam kebijakan, materi pelajaran, dan lingkungannya. Hal tersebut guna menumbuhkan generasi muda penerus bangsa dan agama yang berkompetensi unggul, berakhlak, dan beriman, serta memiliki jiwa moderasi beragama sehingga mereka mampu menempati posisi yang strategis dalam kehidupannya di masyarakat, yakni sebagai;

1. Agen perubahan, yang memiliki arti bahwa pemuda berperan sebagai pusat kemajuan bangsa dan agama

2. Ujung tombak Islam,

3. Sebagai generator, artinya pemuda adalah penggerak menuju kemajuan

4. Sebagai nahkoda, pemuda memiliki tugas dan misi mengarahkan masyarakat untuk mencapai kemajuan.

Uraian di atas menjadi contoh bahwa di dalam pembelajaran telah memuat berbagai contoh pendidikan toleransi. Hal ini pula yang harus diterapkan oleh lembaga pendidikan dalam memuat regulasi/kebijakan dalam mengelola sekolah. Misalnya menghargai, maka pihak sekolah membuat aturan yang dapat menampung atau mewadahi masyarakat yang heterogen khususnya yang menyangkut keyakinan dan kepercayaan. Apabila dikaji dari persoalan jilbab, toleransi dapat ditunjukan dari aturan kewajiban menggunakan jilbab bagi siswinya namun sesuai dengan kepercayaannya, misalnya umat Islam, kristen, Budha menggunakan jilbab sesuai agamanya masingmasing, dengan demikian akan menumbuhkan kesan bangga akan kepercayaannya.

Hal lain seperti bersaudara, kebiasaan bergaul dengan agama lain, menjadikan siswa menumbuhkan kesan akrab dengan teman yang beragama lain akan memberikan pengetahuan baru dalam hal keseharian pemeluk agama lain sehingga tidak menimbulkan diskriminatif. Dengan demikian, siswa dapat memahami dan mengetahui secara benar fakta-fakta dari agama lain, sehingga tidak menimbulkan konflik (toleransi). Selain itu dengan menunjukan perbedaan kepada peserta didik, secara tidak langsung mendidik mereka mengetahui secara luas bahwa mereka tidak hanya hidup di lingkungan komunitas agama tertentu saja, masih ada agama lain yang harus dihormati dan dihargai.

\section{SKB Tiga Menteri dalam Toleransi Beragama Di Lembaga Pendidikan}

SKB Tiga Menteri tentang seragam sekolah memuat tujuh poin. Poin pertama sampai empat menunjukan aturan tentang seragam dan pemenuhan hak dan kebebasan siswa menggunakan seragam. Poin lima sampai tujuh membahas sanksi bagi pihak yang melanggar isi dari SKB. Menteri Agama Republik Indonesia optimis SKB Tiga Menteri tentang seragam sekolah mampu menguatkan sikap toleransi dan kesepahaman antar pemeluk agama (Kontri, 2021). 
Dalam peluncuran SKB, Menteri Pendidikan dan Kebudayaan (Mendikbud), menguraikan tiga hal penting yang menjadi pertimbangan dalam menyusun SKB tiga Menteri ini. Pertama, bahwa sekolah memiliki peran penting dan tanggung jawab dalam menjaga eksistensi ideologi dan konsensus dasar bernegara, yaitu Pancasila, Undang-Undang Dasar Negara Republik Indonesia Tahun 1945, keutuhan Negara Kesatuan Republik Indonesia dan Bhinneka Tunggal Ika serta membangun dan memperkuat moderasi beragama dan toleransi atas keragaman agama yang dianut peserta didik, pendidik, dan tenaga kependidikan. Kedua, sekolah berfungsi untuk membangun wawasan, sikap, dan karakter peserta didik, pendidik, dan tenaga kependidikan untuk memelihara persatuan dan kesatuan bangsa. Serta membina dan memperkuat kerukunan antar umat beragama. ketiga, pakaian seragam dan atribut bagi peserta didik, pendidik, dan tenaga kependidikan pada jenjang pendidikan dasar dan menengah di lingkungan sekolah yang diselenggarakan pemerintah daerah merupakan salah satu bentuk perwujudan moderasi beragama dan toleransi atas keragaman agama (Kementerian Pendidikan Dan Kebudyaan, 2021).

Kebijakan yang dibuat oleh pemerintah bertujuan untuk mewujudkan pendidikan yang lebih baik, khususnya dalam kajian ini yaitu toleransi antar umat beragama. Bagaimanakah SKB Tiga Menteri dalam mewujudkan toleransi antar umat beragama dalam dunia pendidikan diuraikan penulis sebagai berikut.

1. Sekolah berperan dan bertanggung jawab dalam menjaga eksistensi dan konsensus dasar bernegara

Poin pertama tersebut sejalan dengan Pendidikan sebagai pengembangan warga negara yang bertanggung jawab (Tilaar and Nugroho, 2016: 27). Setiap warga negara memiliki hak dan kewajiban masing-masing yang di lindungi oleh negara. Oleh karena itu pendidikan harus mengembangkan individu menjadi warga negara yang baik yang sadar akan hak dan tanggung jawabnya dalam kehidupan beragama, masyarakat, berbangsa dan bernegara demi terwujudnya masyarakat madani. Misalnya hak dan kebebasan untuk memeluk agama tertentu (pasal 28 E UUD 1945). Berdasarkan regulasi tersebut kebijakan-kebijakan yang dibuat oleh lembaga sekolah harus memperhatikan aspek agama tanpa menghalangi atau mengurangi kebebasan dan tanggung jawabnya sebagai mahkluk beragama serta menjaga konsensus negara yaitu Pancasila, khususnya sila pertama.

Konsep tersebut terkait pengalaman nilai-nilai pancasila, di mana sekolah mengambil peran penting dalam mendidik generasi muda. Apabila ditarik ke persoalan jilbab maka dengan penerapan jilbab tersebut merupakan bagian dari penerapan pancasila sila ke-1, yang berarti mendidik anak didiknya untuk mengamalkan ajaran agamanya secara menyeluruh, misalnya umat Kristen jarang yang memakai jilbab atau umat Islam yang sebelumnya belum menggunakan jilbab menjadi lebih 
konsisten dalam menggunakan jilbab. Akan tetapi yang perlu ditekankan yaitu jilbab yang dipakai adalah sesuai kepercayaan masing-masing, sehingga terwujud peserta didik yang religius.

2. Sekolah memiliki fungsi membangun potensi (wawasan, sikap, dan karakter) peserta didik, pendidik, dan tenaga kependidikan.

Perumusan kebijakan pendidikan harus mengembangkan kepribadian peserta didik yang berakhlak mulia dan religius. Hal ini telah dicantumkan di dalam tujuan pendidikan Nasional Indonesia (Tilaar and Nugroho, 2016: 29). Pengembangan kepribadian bukan hanya dalam bentuk individu/personal akan tetapi juga harus dalam aspek-aspek sosial. Mewujudkan peserta didik yang berkepribadian mulia dan religius merupakan tugas dari lembaga pendidikan.

Pendidikan dinilai sebagai proses transmisi budaya yang telah ada dan terus lestari dari generasi ke generasi. Dengan kata lain pendidikan dianggap sebagai wahana untuk mengajarkan dan mensosialisasikan nilai-nilai norma budaya (Fattah, 2014: 44). Penanaman nilai-nilai positif budaya sangat berperan dalam pembentukan karakter bangsa, terlebih ancaman globalisasi berpotensi melunturkan budaya-budaya luhur bangsa Indonesia. Pendapat yang mengatakan pendidikan budi pekerti dan pendidikan religius dibedakan dengan alasan bahwa pendidikan budi pekerti cakupannya lebih luas sedangkan pendidikan religius erat kaitannya dengan agama tertentu. Anggapan seperti itu merupakan suatu hal yang kurang tepat, mengingat pendidikan religius mengantarkan peserta didik lebih memahami dan mengamalkan ajaran agamanya dan berujung pada terbentuknya budi pekerti yang baik.

Indonesia negara yang terdiri dari suku, ras, dan agama yang beragam hal ini membutuhkan suatu kebijakan yang dapat mengakomodir dan mampu menumbuhkan sikap toleransi dalam diri peserta didik. Misalnya yang tertuang di dalam SKB Tiga Menteri poin satu sampai empat dengan tidak memaksakan peserta didik menggunakan seragam sekolah dengan kekhasan agama tertentu. Namun perlu juga diperhatikan bahwa lembaga pendidikan tidak boleh melarang peserta didik menggunakan seragam yang sesuai dengan agama mereka misalnya jilbab untuk menutup aurat.

Dengan kebijakan yang tepat, maka lembaga pendidikan akan menjelma menjadi pencetak generasi penerus bangsa dan agama yang berkompeten, berakhlak mulia, dan memiliki pemahaman agama yang memadai. Dalam hal ini, persoalan yang menyebabkan keluarnya SKB Tiga Menteri yaitu jilbab. Penulis menilai aturan pihak sekolah yang menerapkan kebijakan peserta didik untuk menggunakan jilbab adalah suatu hal yang baik dan mencerminkan agama-agama di Indonesia yang notabenenya mengajarkan umatnya untuk mengenakan jilbab dan menerapkan prinsip kesetaraan. Sebagaimana diketahui bahwa banyak umat Islam yang tidak mengenakan jilbab karena mereka melihat kawannya tidak menggunakan jilbab. Di samping itu juga memenuhi unsur tujuan 
pembentukan kebijakan pendidikan dan tujuan pendidikan nasional yaitu mewujudkan peserta didik yang bertakwa kepada Tuhan Yang Maha Esa. Akan tetapi perlu di perhatikan bahwa apakah jilbab atau kerudung tersebut sesuai dengan agama peserta didik atau tidak.

3. Pakaian seragam. dan atribut sekolah .merupakan. bentuk perwujudan moderasi beragama dan toleransi atas keragaman agama.

Penggunaan atribut dengan kekhasan agama tertentu merupakan suatu hal yang memang tidak dibenarkan. Akan tetapi dalam persoalan jilbab/kerudung, pihak sekolah dapat menyesuaikan dengan ajaran agama peserta didik. Dengan demikian lembaga sekolah dapat dikatakan sebagai tempat untuk memberikan keteladanan serta meningkatkan pemahaman agama, di samping itu juga mengajarkan keberagaman agama kepada peserta didik.

Seragam sebagai moderasi agama (menghindari tindakan ekstrim) dan diatur di dalam Peraturan Menteri. Pendidikan dan .Kebudayaan Nomor 45 Tahun 2014 tentang pakaian seragam sekolah bagi peserta didik jenjang pendidikan dasar dan menengah. Di pasal 2 pun di sebutkan bahwa tujuan pengaturan seragam untuk meningkatkan nasionalisme, persamaan, persaudaraan serta kesetaraan. Namun perlu dipahami bahwa moderasi beragama tidak melulu hanya terkait atribut seragam akan tetapi kebijakan, materi dan iklim yang ada di lembaga pendidikan pun juga harus menerapkan moderasi beragama, sehingga dapat merangkul semua kalangan.

Apabila berpatokan pada konsep moderasi beragama, juga sangat perlu dipahami bahwa kebijakan menggunakan seragam dengan kekhasan agama tertentu, akan berpotensi berdampak pada agama itu sendiri. Misalnya sebagai contoh siswi non-muslim disyaratkan menggunakan jilbab sesuai agama Islam, kemudian dia melakukan hal yang bertentangan dengan agama Islam atau menyebarkan fitnah dan ujungnya berpotensi mengakibatkan perpecahan antar umat beragama. Dengan demikian moderasi beragama tidak ada artinya hanya sebatas ucapan belaka. Maka dampaknya berimbas pada nama baik agama Islam di mata masyarakat.

Justru akan berbanding terbalik jika kebijakan menggunakan atribut/seragam berdasarkan ajaran agama masing-masing. Penganutnya akan lebih berusaha untuk menjaga harkat dan martabat dirinya sebagai pemeluk agama dan berupaya untuk menghindari perilaku yang bertentangan dengan ajaran agamanya karena mereka ke sekolah memakai/membawa atribut agamanya. Dampak lain yaitu mereka yang menggunakan atribut kekhasan agama lain berpotensi untuk minder dan kehilangan kebanggaan akan agamanya sendiri. Oleh karena itu, sebelum membuat kebijakan, pihak sekolah harus berfikir lebih luas, mempertimbangkan nilai dan norma agama, pemahaman masyarakat, adat istiadat, kebiasaan, serta aturan perundang-undangan yang berlaku. 


\section{KESIMPULAN}

Ajaran mengenakan jilbab memang ada dalam ajaran agama yang diakui di Indonesia, akan tetapi pemaksaan penggunaan jilbab khas agama tertentu bagi non-muslim di lembaga pendidikan merupakan suatu hal yang melanggar HAM dan agama. Persoalan toleransi harus diajarkan kepada siswa guna mencegah konflik antar umat beragama, misalnya dengan tidak menghina penganut agama lain. Sekolah yang menerapkan aturan penggunaan jilbab harus memahami ajaran jilbab di dalam setiap agama masing-masing warga sekolah, dengan kata lain jilbab yang digunakan sesuai dengan kepercayaan mereka. Adanya SKB Tiga Menteri menjadi acuan dalam pembuatan kebijakan sekolah khususnya serang sekolah dengan kekhasan agama.

Oleh karena itu, penting untuk menyusun kebijakan baru pendidikan yang lebih spesifik agar tidak menimbulkan problematika ke depannya. Misalnya pembuatan aturan seragam sekolah yang menampilkan desain/gambar jilbab yang sesuai dengan ajaran agama yang diakui di Indonesia, hal tersebut agar tidak menimbulkan miskonsepsi bagi penyelenggara lembaga pendidikan.

\section{DAFTAR PUSTAKA}

5 Poin Tausiyah MUI Sikapi SKB 3 Menteri Soal Seragam. (2021). Majelis Ulama Indonesia. https://mui.or.id/berita/29633/5-poin-tausiyah-mui-sikapi-skb-3-menteri-soal-seragam/

Akhmad. (2020). Perkembangan Toleransi dalam Pendidikan Islam di Indonesia. Scholastica: Jurnal Pendidikan Dan Kebudayaan, 2(1), 55-62.

Al-Barik, H. binti M. (2017). Ensiklopedia Wanita Muslimah. PT Darul Falah.

Alkitab Perjanjian Baru Dalam Terjemahan sederhana Indonesia (1st ed.). (2014). Andi.

Bahtiar, F. (2021a). FSGI Sebut SKB 3 Menteri Terkait Seragam Sekolah Timbulkan Misinformasi. Edukasi. https://edukasi.sindonews.com/read/328092/212/fsgi-sebut-skb-3-menteri-terkaitseragam-sekolah-timbulkan-misinformasi-1612749771

Bahtiar, F. (2021b). SKB 3 Menteri Tak Mengatur Sanksi, FSGI Minta Dilakukan Revisi. Edukasi. https://edukasi.sindonews.com/read/328112/212/skb-3-menteri-tak-mengatur-sanksi-fsgiminta-dilakukan-revisi-1612753349

Bakar, A. (2015). Konsep Toleransi Dan Kebebasan Beragama. Toleransi: Media Komunikasi Umat Bergama, 7(2), 123-131. https://doi.org/10.24014/trs.v7i2.1426

Departemen Agama RI, Cordova Al-Qur'an \& Terjemah. (2009). Sygma Ezagrafika. 
Fajrul, M. (2020). MENJADIKAN SEKOLAH MUHAMMADIYAH SEBAGAI LADANG DAKWAH BAGI GURU. AL-QALAM Jurnal Kajian Islam \& Pendidikan, 12(2), 28-33.

Fattah, N. (2014). Analisis Kebijakan Pendidikan (3rd ed.). PT Remaja Rosdakarya.

Hendra, T. (2017). Profesionalisme Dakwah Dalam Pemberdayaan Masyarakat. MIYAH: Jurnal Studi Islam, 13(1), 164-177. https://doi.org/http://dx.doi.org/10.33754/miyah.v13i01.126.g96

KBBI. (n.d.). https://kbbi.kemdikbud.go.id/entri/kerudung

Salinan Kebutusan Bersama Tiga Menteri Tentang Penggunaan Seragam dan Atribut Bagi peserta

Didik, Pendidik, dan Tenaga kependidikan Di Lingkungan Sekolah Yang Di Selenggarakan

Oleh pemerintah Daerah Pada Jenjang Pendidikan Dasar Dan Menengah, (2021). https://setkab.go.id/wp-content/uploads/2021/02/SALINAN-SKB-Mendikbud-MendagriMenag-CAP.pdf

Kisman. (2021). Pembentukan Karakter Melalui PendidikanAgama Islam. AL-FURQAN: Jurnal Studi Pendidikan Islam, 9(2), 33-42.

http://ejournal.kopertais4.or.id/sasambo/index.php/alfurqan/article/view/4076/2859

Kontri. (2021). Menag Yaqut Optimistis SKB 3 Menteri soal Seragam Akan Kuatkan Toleransi. Kementerian Agama Republik Indonesia. https://kemenag.go.id/berita/read/515290

KPAI: Siswi Dipaksa Berjilbab di Padang Pelanggaran HAM. (2021). CNN Indonesia. https://www.cnnindonesia.com/nasional/20210123171445-20-597568/kpai-siswi-dipaksaberjilbab-di-padang-pelanggaran-ham

Mokodenseho, S., \& Wekke, I. S. (2017). TOLERANSI BERAGAMA DAN PEMBELAJARAN AGAMA ISLAM: HARMONI MASYARAKAT MINORITAS MUSLIM MANADO. Prosiding Seminar Nasional \&Temu Ilmiah Jaringan Peneliti IAI Darussalam Blokagung Banyuwangi, 67-75.

Mucharomah, M. (2017). Guru di Era Milenial dalam Bingkai Rahmatan Lil Alamin. Edukasia Islamika, 2(2), 172. https://doi.org/10.28918/jei.v2i2.1667

Muhaemin, E. (2017). Dakwah Digital Akademisi Dakwah. Ilmu Dakwah: Academic Journal for Homiletic Studies, 11(2), 341-356. https://doi.org/10.15575/idajhs.v12i.1906

MUI SUMBAR “TANTANG” NADIEM MAKARIM UNTUK KE SUMBAR. (2021). Padang TV. https://www.youtube.com/watch?v=SR9v1FRreME 
Mumin, U. A. (2018). PENDIDIKAN TOLERANSI PERSPEKTIF PENDIDIKAN AGAMA ISLAM ( TELAAH MUATAN PENDEKATAN PEMBELAJARAN DI SEKOLAH ). $A l$ Afkar,Journal for Islamic Studies, 1(2), 15-26. https://doi.org/10.5281/zenodo.3554805

Nurita, D. (2021). SKB Menteri Soal Seragam Sekolah, Menag: Kasus di Padang Hanya Puncak Gunung Es. Tempo.Com. https://nasional.tempo.co/read/1429369/skb-menteri-soal-seragamsekolah-menag-kasus-di-padang-hanya-puncak-gunung-es\#: :text=Gus Yaqut menyebut\%2C latar belakang,tidak sesuai dengan regulasi pemerintah.

Undang-Undang Republik Indonesia Nomor 20 Tahun 2003 Teundang-Undang Republik Indonesia Nomor 20 Tahun 2003 Tentang Sistem Pendidikan Nasional, Pub. L. No. Bab Ii, Pasal 3, 1 (2003)., 1 (2003). www.hukumonline.com

Pemerintah Terbitkan Keputusan Bersama Penggunaan Pakaian Seragam dan Atribut bagi Peserta Didik, Pendidik, dan Tenaga Kependidikan pada Sekolah Negeri. (2021). Kementerian Pendidikan Dan Kebudyaan. https://www.kemdikbud.go.id/main/blog/2021/02/pemerintahterbitkan-keputusan-bersama-tiga-menteri

Rahmi, F. (2016). Jilbab "Bukan" Tradisi Islam. Kompasiana.Com. https://www.kompasiana.com/fadiatur/56f12a87d57a61290983089c/jilbab-bukan-tradisiislam?page=all\#sectionall

RI, kementrian A. (2019). Moderasi Beragama. Badan Litbang dan Diklat Kementerian Agama RI. Saihu, \& Aziz, A. (2020). Implementasi Metode Pendidikan Pluralisme Dalam Mata Pelajaran Pendidikan Agama Islam. Belajea: Jurnal Pendidikan Islam, 5(1), 131-150. https://doi.org/10.29240/belajea.v5

Suryan, S. (2017). Toleransi Antarumat Beragama: Perspektif Islam. Jurnal Ushuluddin, 23(2), 185200. https://doi.org/10.24014/jush.v23i2.1201

Syafi' in, M. (2007). BERJILBAB DALAM TIGA TRADISI AGAMA SAMAWI. Al-Qalam, 24(1), 109-120. https://doi.org/https://dx.doi.org/10.32678/alqalam.v24i1.1658

Syarah, S. (2020). EKSISTENSI TUDUNG KEPALA WANITA DALAM PERSPEKTIF ISLAM DAN HINDU DI INDONESIA [Islam Negeri Syarif Hidayatullah]. http://repository.uinjkt.ac.id/dspace/bitstream/123456789/52053/1/Br Skripsi Siti Syarah.pdf

Tauhid, A. F. N. (2011). Jilbab/Cadar Menurut Ajaran Yahudi, Nasrani, Hindu, Buddha, Kejawen dan Jil. https://gizanherbal.wordpress.com/2011/12/17/jilbabcadar-menurut-ajaran-yahudinasrani-hindu-buddha-kejawen-dan-jil/ 
Tilaar, H. A. ., \& Nugroho, R. (2016). Kebijakan Pendidikan (4th ed.). Pustaka Pelajar.

Usman, M., \& Widyanto, A. (2019). Internalisasi Nilai-Nilai Toleransi dalam Pembelajaran Pendidikan Agama Islam di SMA Negeri 1 Lhokseumawe. DAYAH: Journal of Islamic Education, 2(1), 36. https://doi.org/10.22373/jie.v2i1.2939

Wahyuni, T. (2019). Pembacaan Al-Qur'an Di Ruang Publik: Refleksi Pembentukan Karakter Religius Siswa Ditengah Kepanikanmoral. Jurnal Kajian Kritis Pendidikan Islam Dan Manajemen Pendidikan Dasar, 2(1), 80-98. file://C:/Users/User/Downloads/fvm939e.pdf 